\title{
QUASI OTONOMI PADA PEMERINTAHAN TERENDAH NAGARI SIMARASOK DI SUMATERA BARAT DAN DESA PONJONG DI DAERAH ISTIMEWA YOGYAKARTA
}

\author{
Asrinaldi dan Yoserizal \\ Jurusan Ilmu Politik FISIP Universitas Andalas \\ Kampus Limau Manis, Padang, 25163 \\ E-mail: asrinaldi4@yahoo.com
}

\begin{abstract}
Abstrak Dalam UU Pemerintahan Daerah dinyatakan bahwa titik berat otonomi ada di tingkat kabupaten/kota. Akan tetapi realitanya, urusan pemerintahan yang diserahkan ke kabupaten tersebut juga dilimpahkan kembali kepada pemerintah terendah seperti nagari di Sumatera Barat dan desa di Yogyakarta. Padahal dalam UU, pemerintah terendah seperti nagari dan desa memiliki kewenangan otonomi berdasarkan hak asal usulnya. Faktanya, pelaksanaan kewenangan berdasarkan hak asal usul ini tidak pernah jelas bentuknya dan seperti apa implementasinya. Dengan menggunakan metode penelitian kualitatif dengan kaedah grounded theory, artikel penelitian ini menjelaskan makna otonomi di nagari dan desa berdasarkan hak asal usul yang belum mampu diidentifikasi oleh pemerintah terendah tersebut. Selain itu, artikel ini juga menjelaskan implikasi dari pelaksanaan urusan yang dilimpahkan pemerintah kabupaten kepada pemerintah nagari dan desa. Hal penting yang ditemukan dalam tulisan ini adalah ternyata pemerintah memang mengabaikan kewenangan pemerintah terendah dalam melaksanakan hak asal usulnya. Akibatnya pemerintah nagari dan desa lebih memilih pelaksanaan urusan yang dilimpahkan kepadanya untuk menunjang keberhasilan penyelenggaraan otonomi daerah yang ada di kabupaten.
\end{abstract}

Kata Kunci: quasi otonomi dan pemerintahan terendah

\section{QUASI AUTONOMY AT THE LOWEST GOVERNMENT: SIMARASOK VILLAGE IN WEST SUMATERA PROVINCE AND PONJONG VILLAGE IN YOGYAKARTA PROVINCE}

\begin{abstract}
Local Government Law illuminate the emphasis of local autonomy is at the district level. However, in fact, the district government with its autonomy tend to submit its affairs to the lowest government such as nagari in West Sumatera and desa in DI Yogyakarta. Whereas in the Act, nagari and desa have the autonomous rights based on its origins. However, this autonomy rights has never been clear what its shape and implementation. By using qualitative research methods with grounded theory techniques, this article explains what the real meaning of local autonomy in the district and why local governments also delegate part of his affairs to nagari and desa government. In addition, this paper also explains what the implications of the implementation of the district government affairs delegated to the government of nagari and village. Important finding in this paper is the district government tend to ignore the nagari rights to accomplish its authority based on its origins rights. Consequently, nagari and desa government prefers to implement of the district affairs that delegated to nagari to support regional autonomy in the district area.
\end{abstract}

Key Words: Quasi autonomy and The lowest government

\section{PENDAHULUAN}

Penyelenggaraan prinsip desentralisasi di Indonesia menyisakan persoalan mendasar, terutama dalam meletakkan titik berat otonomi. Dalam UU Pemerintahan Daerah ditegaskan bahwa titik berat otonomi ada di tingkat kabupaten/kota. Namun, pada aspek lain, otonomi di tingkat terendah seperti nagari, desa atau dengan sebutan lain yang setingkat dengannya juga memiliki otonomi asli berdasarkan hak asal usul, yaitu dari segi sosiobudaya yang berkembang dalam masyarakat. Akan tetapi, hak asal usul pemerintah desa tersebut tidak pernah dijelaskan lebih jauh sehingga yang dipahami tentang hak asal usul ini adalah sekedar pelaksanaan adat istiadat dan turunanya saja. Padahal hak asal usul ini memiliki makna yang luas yang juga melaksanakan fungsi pemerintahan seperti yang dilakukan jauh sebelum Republik Indonesia ini berdiri. Namun, setelah diintegrasikan ke dalam penyelenggaraan sistem pemerintahan modern nagari dan desa 
justru tidak lagi melaksanakan hakikat hak asal-usul tersebut. Yang ada justeru menyelenggarakan urusan pemerintahan yang diserahkan oleh pemerintah kabupaten.

Di Sumatera Barat, bentuk pemerintahan terendah dikenal dengan sebutan nagari. Nagari adalah kesatuan masyarakat hukum adat memiliki wilayah pemerintahan dan masyarakatnya sendiri. Menurut sejarahnya nagari adalah daerah-daerah oto-nom yang berdaulat melaksanakan fungsi pemerintahan sendiri, namun tergabung dalam konfederasi Kerajaan Pagaruyung (De Jong, 1952). Namun, selepas Indonesia merdeka kewenangan dan urusan nagari di Sumatera Barat mengalami gradasi yang signifikan. Nagari tidak lagi melaksanakan urusan rumah tangganya sendiri, kecuali hanya pelimpahan urusan dari pemerintah pemerintah kabupaten dan urusan adat istiadat. Bahkan ada kesan kewenangan otonomi nagari yang berasal dari hak asal usul tersebut diintegrasikan ke dalam kewenangan dalam melaksanakan urusan yang ditugaskan oleh pemerintah kabupaten (Asrinaldi \& Yoserizal, 2011a). Praktik pemerintahan seperti ini bertentangan dengan hakikat otonomi asli yang berasal dari hak asal-usul yang dilaksanakan di tingkat pemerintahan terendah sesuai dengan UU.

Begitu juga di Yogyakarta, desa sebagai bentuk pemerintahan terendah berbeda dengan nagari. Desa adalah ke-satuan masyarakat hukum yang memiliki batas wilayah, namun tidak mendasari aktivitas sosial, politik dan pemerintahan pada sistem adat istiadat seperti di nagari. Di sini terlihat bahwa kesatuan hukum masyarakat desa sebenarnya lebih dibatasi oleh wilayah tempat komunitas di dalam desa tersebut bermukim dan berinteraksi. Dalam banyak hal, desa juga menyelenggarakan urusan pemerintahan yang dilimpahkan oleh pemerintah kabupaten.

Menariknya, walaupun nagari dan desa diakui otonomi aslinya, namun dalam realitanya kedua kesatuan masyarakat hukum ini lebih banyak menyelenggarakan urusan pemerintahan yang dilimpahkan pemerintah kabupaten. Bagaimana pun, pelaksanaan fungsi pemerintahan terendah seperti ini tentu merancukan pelaksanaan otonomi daerah itu sendiri. Sebab, makna otonomi daerah di tingkat kabupaten adalah penyelenggaraan urusan pemerintahan yang sudah diserahkan oleh pemerintah kepadanya berdasarkan PP No.38/2007.

Artikel ini bertujuan menjelaskan hakikat pelaksanaan otonomi asli di tingkat nagari dan desa dalam penyelenggaraan otonomi daerah. Di samping itu, artikel ini juga menjelaskan bagaimana pelaksanaan otonomi asli yang ada di nagari dan desa berdasarkan hak asal usulnya yang diakui oleh UU. Selain itu, artikel ini juga menjelaskan dampak pelimpahan urusan pemerintahan oleh pemerintah kabupaten kepada pemerintah nagari dan desa. Karena itu, agar penjelasan dalam artikel ini lebih fokus, maka pada bagian awal dibahas pengertian otonomi daerah dan hubungannya dengan otonomi di tingkat nagari dan desa dari aspek tinjauan literatur. Pada bagian selanjutnya juga dibahas temuan empiris dari hasil kajian di Sumatera Barat dan Yogyakarta terkait dengan hakikat otonomi asli dalam pelaksaaan otonomi daerah.

\section{Otonomi Daerah Atau Otonomi Desa:sebuah Tinjauan Literatur}

Pelaksanaan otonomi daerah sebenarnya berangkat dari konsep desentralisasi, yaitu penyerahan kewenangan dari pemerintah kepada unit-unitnya yang ada di daerah. Bahkan secara umum, desentralisasi menurut Rondinelli \& Cheema (1983:18) diperluas tidak hanya menyangkut penyerahan kewenangan kepada unit pemerintah di bawahnya atau yang dikenal dengan devolusi, tapi juga delegasi ke-wenangan ke semi otonomi, dekonsentrasi dan bahkan privatisasi. Karenanya otonomi daerah tersebut memiliki aspek yang luas, tidak hanya kekuasaan politik an sich, tapi juga meliputi kewenangan administrasi, aspek finansial dan kewenangan yang dibagi bersama dengan pemberi kewenangan (Turner \& Hulme, 1997; Cheema, 2005). Atas dasar inilah sebenarnya otonomi daerah itu dilaksanakan.

Lebih jauh, Berman (2003:1) men- 
jelaskan bahwa otonomi daerah juga berhubungan dengan kemampuan daerah melaksanakan urusannya sendiri secara leluasa sesuai dengan aturan yang berlaku. Dalam pelaksanaan urusan rumah tangga tersebut harus diiringi dengan kemampuan daerah menentukan (local self-determination) dan memenuhi sendiri (local self-sufficiency) kebutuhan untuk melaksanakan urusanurusan yang diserahkan tersebut. Bahkan otonomi daerah sebenarnya terkait dengan kemampuan pejabat pemerintah di daerah membuat keputusan yang bermanfaat bagi kepentingan daerah dan masyarakat. Tulia G. Falleti dalam bukunya Decentralization and subnational politics in Latin America (2010) menegaskan pentingnya asistensi dari pemerintah sehingga daerah data mengembangkan kemandiriannya dalam berotonomi baik dari segi pembiayaan maupun penyelenggaraan kewenangan dalam praktik pemerintahan, khususnya di tingkat terendah. "Decentralization of government policies that emphasized the principle of subsidiarity (of collecting, spending, and making public-policy decisions at the lowest possible level of government) proved functional to those larger political and economic changes" (2010:2). Singkatnya, desentralisasi yang wujudnya dalam bentuk otonomi daerah ini ditekankan pada pengembangan fungsi-fungsi kebijakan ekonomi dan politik di tingkat terendah.

Pengertian lain tentang otonomi daerah berhubungan dengan konsep desentralisasi. Walaupun keduanya identik, tapi memiliki perbedaan. Istilah otonomi daerah lebih mengarah pada pelaksanaan politik dan kekuasaan negara. Sementara, istilah desentralisasi merujuk kepada persoalan administrasi dari pemerintahan atau negara. Walaupun begitu, jika dilihat dari pelaksanaan kekuasaan negara yang dibagi ke daerah, maka kedua istilah ini memiliki keterkaitan yang erat (I Nyoman Sumaryadi, 2005:23-24). Karenanya, bentuk kekuasaan negara yang dilaksanakan tersebut adalah pemberian kewenangan untuk melaksanakan urusan yang sudah diserahkan pemerintah kepada pemerintah daerah.

Namun, yang jadi persoalan adalah sejauh mana urusan rumah tangga tersebut diberikan oleh negara kepada suatu daerah.
Sebab,jelastidaksemuadaerahyangmemiliki kemampuan yang sama dan kemampuan untuk memenuhi kebutuhannya sendiri dalam melaksanakan urusan rumah tangga yang diserahkan kepadanya. Faktanya, dalam penyelenggaraan pemerintahan di Indonesia, pemerintah cenderung menyeragamkan pemaknaan otonomi ini sehingga otonomi daerah ada di kabupaten/kota. Konsekuensinya semua pemerintah daerah melaksanakan kewenangan dan urusan yang sama karena dianggap memiliki kemampuan melaksanakan urusan tersebut dan memiliki keupayaan yang sama untuk memenuhi kebutuhannya sendiri, terutama dalam melaksanakan urusan yang diserahkan. Padahal, jika dilihat secara teliti, ternyata tidak semua daerah yang memiliki kemampuan memenuhi kebutuhannya sendiri. Dalam banyak aspek ilmuwan menyadari perlunya penerapan otonomi yang lebih luas bagi pemerintah terendah dan tidak hanya menekankan pada aspek penyeragaman. Justru yang dipentingkan adalah pelaksanaan otonomi daerah yang asimetris. Ini didasarkan pada fakta bahwa kemampuan daerah dalam merencanakan, membiayai, melaksanakan dan mengevaluasi kewenanangan melaksanakan pemerintahan tidaklah sama.

Seiring dengan perkembangan masyarakat, maka hubungan pusat-daerah juga mengalami perubahan yang berarti. Terbitnya UU No.32/2004 semakin mengukuhkan peran pemerintah dalam mengendalikan pelaksanaan otonomi daerah. Masalah penyelenggaraan pemerintahan daerah seperti desentralisasi fiskal, ketegangan antara DPRD dan kepala daerah dan mekanisme pemilihan kepala daerah diubah semua oleh pemerintah pusat tanpa melalui diskusi publik. "Akibatnya posisi para administrator daerah di satu pihak menjadi lebih dependen pada negara pusat, tetapi di pihak lain menjadi lebih kuat dalam hubungan dengan DPRD" (Nordholt \& Klinken, 2007:20). Tidak hanya itu, kewenangan dan urusan yang dilimpahkan juga diatur ketat sehingga daerah harus melaksanakan urusan secara konsisten. Misalnya, ini dapat dilihat dari pelaksanaan 
urusan wajib yang mesti didahulukan karena menyangkut kebutuhan riil masyarakat untuk dilayani sebelum mengerjakan urusan pilihan. Hal ini juga membawa dampak pada pelaksanaan otonomi daerah terjebak pada pelaksanaan urusan pemerintahan rutin sehingga melupakan hakikat otonomi yang mendorong adanya kreativitas dan inovasi daerah.

Syarif Hidayat (2010) menjelaskan kebijakan revisi UU No.22/1999 dan UU No.25/1999 menjadi UU No.32/2004 dan UU No.33/2004 dilihat sebagai bentuk kebijakan pragmatis-parsialistik negara (2010:4). Menurutnya praktik otonomi daerah setelah sepuluh tahun dilaksanakan justru menimbulkan bias-bias, terutama dalam aspek relasi negara-masyarakat. Ini semua bermula dari persaingan antara elite penguasa dengan elite massa yang berusaha saling mengambil peran untuk kepentingan masing-masing. Akibat kecenderungan ini, munculah disorientasi dalam penyelenggaraan desentralisasi di Indonesia (2010:14-15). Sesuai dengan kesimpulan Syarif, bias-bias dalam penyelenggaraan desentralisasi tersebut dapat diminimumkan melalui penguatan kapasitas negara (state capacity) melalui reformasi institusi negara agar tujuan desentralisasi dapat diwujudkan.

Penguatan peranan negara memang pilihan yang logis ketika kekuatan masyarakat mulai menguat dalam negara. Penguatan peranan negara ini sebenarnya menjadi bagian dari otonomi negara sehingga negara dapat mengendalikan kekuatankekuatan dalam masyarakat yang mencoba membelokan tujuan bernegara (Nordlinger, 1981; Skocpol, 1985). Praktik otonomi negara ini semakin jelas, terutama dalam melihat pelaksanaan otonomi daerah, yaitu pemerintah mengendalikan pelaksanaan otonomi daerah yang memang pada awalnya bermasalah pasca jatuhnya rezim Orde Baru (Aspinall \& Fealy, 2004). Namun, intervensi negara dengan diterbitkannya UU No.32/2004 menggantikan UU No.22/1999 menunjukan perbaikan yang cukup berarti dalam pelaksanaan otonomi daerah, terutama dalam mengendalikan kekuatan sosial dalam masyarakat yang memiliki agenda yang bertentangan dengan kepentingan negara (Asrinaldi, 2012:96). Namun, pertanyaannya apakah agen-da negara tersebut sudah dilaksanakan secara konsisten oleh aparatur pemerintah daerah? Apalagi pelaksanaannya dikaitkan dengan melibatkan kesatuan masyarakat hukum adat yang memiliki hak asal usul. Bagaimana pun aspek ini perlu dijelaskan agar intervensi yang dilakukan pemerintah ini tidak mengabaikan keaslian masyarakat dalam melaksanakan demokrasi, terutama dalam penyelenggaraan pemerintahan terendah di Indonesia.

Keberhasilan pelaksanaan otonomi daerah tidak hanya terkait dengan pelimpahan kewenangan saja, tapi juga aspek kepemimpinan yang melaksanakannya. Penelitian yang dilakukan Bank Dunia (2004) menemukan masih belum maksimalnya faktor kepemimpinan dalam pelaksanaan otonomi daerah, terutama dalam melaksanakan pelayanan publik. Akibatnya pelayanan publik yang inovatif tidak banyak ditemukan dalam pelaksanaan fungsi pemerintahan di era desentralisasi ini Penelitian ini menemukan bahwa keberhasilan inovasi pelayanan publik yang dilakukan pemimpin daerah juga tidak di dukung oleh sistem perundangan nasional sehingga inovasi yang dilakukan aparatur pemerintahan justru berakhir pada masalah hukum. Bahkan penelitian ini menemukan pelayanan publik yang dilaksanakan belum dijadikan program utama untuk masyarakat, khususnya di tingkat bawah. Akibatnya masyarakat kelas bawah cenderung tidak diuntungkan dengan program pelayanan publik tersebut.

Jika dipahami, tujuan otonomi daerah adalah untuk mewujudkan kualitas pelayanan publik, terutama di tingkat pemerintahan terendah. namun, dalam banyak hal pelaksanaan fungsi pelayanan publik sebagai fungsi yang penting dalam penyelenggaraan pemerintahan belum dapat dilaksanakan dengan baik di tingkat pemerintahan terendah.

Kewenangan melaksanakan urusan pemerintahan di tingkat terendah ini belum ditemukan secara jelas, kecuali hanya me- 
laksanakan urusan yang telah dilimpahkan oleh pemerintah kabupaten. Artinya, pemerintah terendah seperti nagari dan desa belum dapat melaksanakan kewenangan otonomi aslinya berdasarkan hak asal usul, yaitu kewenangan yang melekat dengan sejarah kemunculan unit pemerintahan terendah ini. Fakta yang terjadi baik di nagari maupun di desa memunculkan pertanyaan, apakah otonomi nagari dan desa tersebut masih ada?

Secara yuridis, pemerintah memang mengakui adanya otonomi asli di nagari dan desa ini. Namun, faktanya otonomi asli ini belum terlihat dilaksanakan sepenuhnya. Padahal pengembangan otonomi di nagari dan desa adalah hal penting yang harus dilaksanakan agar fungsi pemerintahan terendah dapat dilaksanakan. Apalagi dalam rangka melaksanakan demokrasi lokal sesuai dengan tujuan otonomi daerah. Menurut Antlov (2004) otonomi desa ini seiring sejalan dengan pelaksanaan demokrasi di tingkat terendah. Antlov menjelaskan praktik demokrasi mulai berkembang di desa yang dapat dilihat dengan menguatnya fungsi Badan Perwakilan Desa (BPD) yang dapat memfasilitasi kepentingan masyarakat desa sehingga pemerntah desa dapat melaksanakan fungsinya dengan baik. Namun, dari segi lain, keberadaan demokrasi di desa juga mendapat ancaman dari institusi yang berada di luar komunitas masyarakat desa itu sendiri, yaitu negara dan elite lokal. "...the main threat to grassroots democracy and village autonomy comes from outside the communities, from the state and from district elites. I am referring to the half-hearted measures through which central and district governments support village autonomy, and the way local elites have captured the fruits of decentralisation. To what extent higher authorities will allow villages to maintain their autonomy is still very uncertain" (Antlov, 2003:210).

Praktik berdemokrasi di desa, termasuk pelaksanaan fungsi pemerintahan di tingkat terendah ini justru dikendalikan sedemikian rupa oleh negara. Bahkan jika dikaitkan dengan praktik otonomi, kendali yang dilakukan oleh negara pada masa Orde
Baru yang dilaksanakan mempengaruhi hakikat otonomi desa. Bahkan menurut Yando Zakaria (2004:1), pada dasarnya tidak ada lagi yang namanya otonomi desa itu. Yando menegaskan bahwa hilangnya otonomi desa selama ini adalah dampak dari dominannya negara Orde Baru mencampuri urusan desa yang justru mementingkan aspek administrasi pemerintahan di desa dalam konteks administrasi negara modern. Padahal desa sebenarnya juga memiliki "governance system (sistem pegelolaan dan atau pengurusan hidup bersama) yang ada di tingkat komunitas, dimana di dalamnya tercakup government system (sistem pemerintahan)." Namun, karena adanya intervensi negara Orde Baru, maka terjadi perubahan yang cukup signifikan dalam struktur dan pranata sosial di desa. Tidak hanya itu, substansi kewenangan yang dimiliki desa pun menjadi kabur. Walaupun secara yuridis ada pengakuan kewenangan otonominya, terutama dari hak asal usul. Dalam realitanya, otonomi desa berdasarkan hak asal usul ini hanya pengakuan dalam UU saja, namun sulit dilihat dalam praktik pemerintahan terendah.

Lalu, bagaimana hakikat otonomi desa dalam konteks penyelenggaraan urusan pemerintahandidesatersebut? DalamUndang - undang No. 32 Tahun 2004 disebutkan urusan pemerintahan yang menjadi kewenangan desa mencakup (1) urusan pemerintahan yang sudah ada berdasarkan hak asal usul desa, (2) urusan pemerintahan yang menjadi kewenangan kabupaten/kota yang diserahkan pengaturannya kepada desa, (3) tugas pembantuan dari Pemerintah, Pemerintah provinsi, dan atau pemerintah kabupaten/kota dan yang terakhir (4) urusan pemerintahan lainnya yang oleh peraturan perundang-perundangan diserahkan kepada desa. Namun, bagaimana elaborasi yang jelas terkait dengan kewenangan tersebut belum dijabarkan oleh pemerintah, terutama yang berhubungan dengan hak asal usul yang sebenarnya menjadi bagian penting dari otonomi desa. Malah kecenderungan dalam praktik pemerintahan terendah, pemerintah kabupaten lebih menekankan aspek tugas pembantuan kepada desa disertai dengan 
pembiayaan-pembiayaan. Akibatnya baik pemerintah nagari maupun desa saling berlomba menerima pelimpahan urusan dari pemerintah kabupaten karena disertai dengan sejumlah dana sehingga melupakan hak asal usulnya.

\section{METODE}

Penelitian ini dilakukan dengan menggunakan pendekatan kualitatif dengan teknik grounded theory. Pendekatan kualitatif dengan menggunakan teknik grounded theory ini bertujuan untuk menemukan konsep dan proposisi terkait dengan pelaksanaan otonomi di tingkat pemerintahan terendah dengan menitikberatkan lokasi penelitian pada nagari di Sumatera Barat dan desa di Yogyakarta yang keduanya memiliki hak otonomi yang berdasarkan hak asal-usulnya. Pengumpulan data primer dilakukan di Nagari Simarasok Kabupaten Agam Provinsi Sumatera Barat dan Desa Ponjong di Provinsi DI Yogyakarta. Kedua nagari dan desa ini adalah pemenang lomba desa terbaik di tingkat nasional tahun 2011. Pengumpulan data dilakukan dengan menggunakan kaedah wawancara dan observasi yang selanjutnya dilengkapi dengan data sekunder yang relevan untuk dianalisis.

\section{HASIL DAN PEMBAHASAN}

Bagian ini difokuskan pada dua pembahasan utama, yaitu hakikat otonomi desa dalam penyelengaraan otonomi daerah di kabupaten dan dampak pelimpahan urusan pemerintahan dari pemerintah kabupaten ke pemerintah nagari dan desa.

\section{Hakikat Pelaksanaan Otonomi Asli Di Nagari Dan Desa Dalam Penyelenggaraanotonomi Daerah}

Secara umum praktik otonomi daerah di Indonesia sebenarnya sudah berada pada jalur yang benar. Ini ditandai dengan semakin membaiknya pelayanan publik dan pembangunan di beberapa daerah. Paling tidak, otonomi daerah sudah mengarah pada apa yang diinginkan oleh masyarakat. Walaupun begitu, dari segi lain, memang masih ada keluhan masyarakat terkait dengan pelaksanaan fungsi pemerintahan di daerah. Pemerintah menyadari adanya keluhan masyarakat tersebut sehingga untuk meminimumkan dampak negatifpelaksanaan otonomi daerah, maka dilakukan evaluasi terhadap dasar hukumnya. Salah satu luaran evaluasiyang dilakukanpemerintahiniadalah direvisinya undang-undang pemerintahan daerah agar praktik desentralisasi ini dapat diperbaiki. Karenanya dari waktu ke waktu selalu akan dijumpai revisi-revisi undangundang pemerintahan daerah ini mengikuti dinamika perkembangan masyarakatnya.

Revisi terhadap UU No.5/1974 menghasilkan UU No.22/1999. Namun, sejumlah kelemahan dalam UU No.22/1999 ini mendorong pemerintah melakukan revisi sehingga berakhir dengan terbitnya UU No.32/2004. Berangkat dari fenomena dalam masyarakat, maka undang-undang pemerintahan daerah yang dilaksanakan sekarang ini pun sedang dibahas perubahannya di lembaga legislatif. Rencananya pemerintah memisahkan pengaturan pelaksanaan pemilihan kepala daerah dan desa sehingga keduanya dapat dilaksanakan maksimal. Justru dengan mengintegrasikan masalah ini ke dalam satu undang-undang berdampak pada masyarakat, terutama dalam melaksanakan demokrasi lokal.

Aspek penting yang menjadi perhatian dalam penyelenggaraan pemerintahan di daerah adalah hubungan kewenangan antara pemerintah provinsi dan kabupaten. Namun, akhir-akhir ini kembali mencuat, apa yang menjadi kewenangan nagari/desa sebagai daerah otonom berdasarkan hak asal usulnya. Khusus hubungan kewenangan pemerintah kabupaten dan desa mendapat perhatian karena terkait dengan hakikat otonomi daerah yang dilaksanakan. Dalam UU No.32/2004 dinyatakan bahwa titik berat pelaksanaan otonomi daerah ada di kabupaten/kota. Menitikberatkan dasar pelaksanaan otonomi daerah di kabupaten/kota ini tentu memiliki pertimbangan. Pertama, terkait dengan hubungan emosional masyarakat dengan elite pemerintahan yang sangat dekat sehingga dapat membantu pelaksanaan fungsi pemerintahan sehingga akuntabilitas dan responsivitas pemerintah dapat diwujudkan. Kedua, penyelenggaraan fungsi pemerintahan dengan wilayah geo- 
grafis dan aspek demografi di daerah kabupaten/kota memungkinkan pemerintah melakukan kendali langsung terhadap aktivitas masyarakat secara langsung. Ketiga, interaksi masyarakat yang sangat mendalam karena saling mengenal sehingga memudahkan munculnya partisipasi masyarakat dalam pelaksanaan pembangunan. Yang lebih penting, dengan menitik beratkan otonomi daerah di daerah kabupaten/kota ini mendorong prakarsa masyarakat dalam pelaksanaan pembangunan (Ryaas Rasyid, 2005:10).

Selain itu, dengan meletakkan titik berat otonomi di daerah kabupaten/kota ini juga membawa manfaat pada keterlibatan masyarakat dalam proses politik. Selama ini partisipasi politik masyarakat dibatasi sehingga kesadaran masyarakat berpolitik menjadi rendah. Ini adalah implikasi dari tidak berjalannya pendidikan politik. Jadi dengan diberikannya otonomi daerah, maka mendorong masyarakat terlibat dalam membangun sistem demokrasi lokal yang lebih baik (cf. Rondinelli \& Chemma, 1983; Smith, 1985).

Namun, dari sisi lain, titik berat otonomi di daerah kabupaten/kota ini juga sebenarnya memiliki masalah apabila dihubungkan dengan kesatuan masyarakat hukum yang dikenal dengan desa. Desa atau nama lain yang digunakan di beberapa daerah juga memiliki hak otonomi berdasarkan hak asal-usulnya. Kewenangan yang dilaksanakan berdasarkan hak asalusul ini belum pernah diimplementasikan oleh masyarakat desa. Padahal kewenangan desa berdasarkan hak asal-usul ini bagian penting dalam pelaksanaan demokrasi lokal. Otonomi desa adalah hal penting dalam praktik pemerintahan terendah di Indonesia yang sebenarnya jauh hadir sebelum negara Indonesia wujud (Yando Zakaria. 2004). Kesatuan masyarakat desa yang memiliki ikatan hukum berdasarkan nilai adat dan budaya menjadi faktor penguat masyarakat untuk memainkan perannya di desa. Bahkan Seavoy (2003:146) menegaskan bahwa otonomi di tingkat terendah adalah bagian penting dalam kehidupan masyarakat, tidak hanya memperkuat norma adat, tapi juga kebersamaan dalam menjalani kehidupan. Bahkan, pasca kolonialisasi di negaranegara di Asia dan Afrika, otonomi desa ini bahkan menjadi basis pembentukan negara bangsa modern.

Jika ditelusuri sejarah sebelum Indonesia merdeka, pemerintah Hindia Belanda mengakui keberadaan desa ini sebagai kesatuan masyarakat hukum yang menyelenggarakan pemerintahan sendiri(self bestuur). Ini bertujuan untuk memperkuat administrasi pemerintahan kolonial, yaitu memudahkan mereka untuk memobilisasi dan mengendalikan masyarakat pribumi pada waktu itu. Hakikat penyelenggaraan pemerintahan sendiri tersebut adalah bagian dari otonomi desa. Namun, faktanya sekarang, otonomi desa yang menjadi dasar pelaksanaan pemerintahan terendah tidak mendapat perhatian pemerintah. Malah, pemerintah mengintegrasikan pelaksanaan otonomi desa ini ke dalam penyelenggaraan fungsi pemerintahan di kabupaten. Akibatnya hak asal usul yang menjadi basis pelaksanaan otonomi daerah di desa tidak dapat dikembangkan baik oleh pemerintah desa maupun masyarakatnya. Padahal asal usul ini adalah hak bawaan yang harus diakui oleh negara dan dilaksanakan sejalan dengan penyelenggaraan pemerintahan modern di tingkat terendah (Yando Zakaria, 2004:42-44). Yang terjadi justru pemerintah kabupaten melimpahkan sebagian urusannya kepada pemerintah nagari dan desa sehingga pemerintah terendah ini tidak dapat mengembangkan apa yang menjadi hak asalusulnya.

Otonomi asli di nagari dan desa berdasarkan hak asal-usul memang belum dapat dilaksanakan karena sebenarnya pemerintah juga kesulitan mengidentifikasi kewenangan apa sesungguhnya yang terkait dengan hak asal-usul tersebut. Menariknya hubungan yang terbangun di antara peringkat pemerintahan ini justru hubungan subordinasi, antara pemerintah kabupaten dan pemerintah desa. Faktanya, pemerintah desa hanya melaksanakan urusan yang dilimpahkan oleh pemerintah kabupaten yang legalitasnya ditentukan oleh pemerintah kabupaten. ${ }^{1}$ Yang terlihat

\footnotetext{
1 Wawancara dengan Siswanto Kabag Administrasi Pemerintahan Desa Kab. Gunung Kidul pada 25 Juni 2013 Sekretariat Pemda Kab Gunung Kidul DI Yogyakarta.
} 
justru pemerintah desa hanya memiliki kewenangan yang dilimpahkan bukan diserahkan kepadanya melalui kecamatan. Bahkan dengan banyaknya urusan yang dilimpahkan pemerintah kabupaten menyebabkan pemerintah desa kewalahan untuk melaksanakan tugas dan fungsinya dengan baik karena keterbatasan yang dimilikinya.

Hal ini juga terjadi pada pemerintahan nagari di Sumatera Barat. Pada dasarnya penyelenggaraan urusan pemerintahan nagari tidak lain adalah melaksanakan urusan yang dilimpahkan pemerintah kabupaten. ${ }^{2}$ Hasil penelitian Bakaruddin et al. (2004) berkesimpulan bahwa tidak semua nagari dapat melaksanakan urusan yang dilimpahkan kepadanya karena keterbatasan yang dimiliki oleh pemerintah nagari. Kajian ini dilakukan di kabupaten Solok yang menemukan bahwa nagari hanya mampu melaksanakan 10-20 urusan atau 9,5-19,5 persen saja urusan pemerintahan yang dilimpahkan kepadanya. Padahal urusan yang diterima jumlahnya mencapai 105 urusan. Tidak terlaksananya urusan nagari ini adalah implikasi keterbatasan sumber daya yang dimiliki oleh pemerintah nagari.

Tentu ini juga berdampak kepada keinginan pemerintah nagari menggali apa yang menjadi hak asal usulnya yang dinyatakan dalam undang-undang. Realitanya pemerintah nagari baru sebatas melaksanakan kewenangan dalam urusan pemerintahan yang dilimpahkan oleh pemerintah kabupaten dan hak lain dalam bidang adat dan budaya. ${ }^{3}$ Gejala ini sangat paradoks dengan semangat otonomi daerah yang dilaksanakan. Padahal ditinjau dari aspek sejarahnya, hakikat bernagari di Sumatera Barat hampir sama dengan hakikat bernegara dengan fungsi-fungsinya yang sebenarnya bersumber dari kemunculan nagari itu sendiri. Jika dilihat lebih jauh, pada dasarnya nagari juga memiliki fungsi ekstraksi dan distribusi yang tercermin dalam kewenangan mengurus pusako oleh penghulu adat. Sementara, fungsi regulasi

\footnotetext{
2 Wawancara dengan Muslim Dt. Payung Diaceh Wali Nagari Simarasok pada 4 Juli 2013 di Kantor Wali Nagari.

3 Wawancara dengan Muslim Dt. Payung Diaceh Wali Nagari Simarasok pada 4 Juli 2013 di Kantor Wali Nagari.
}

dan fungsi simbolik sebuah negara juga tercerminkan dalam kewenangan mengurus sako.

Hal yang sama juga berlangsung di desa-desa di Yogyakarta. Hakikat otonomi desa mulai memudar seiring dengan kuatnya campur tangan pemerintah kabupaten dalam pelaksanaan fungsi pemerintahan hingga ke tingkat terendah. Dalam batasan tertentu, sebenarnya bentuk otonomi desa itu dapat dilihat dari pengelolaan irigasi yang melibatkan pemerintah dan masyarakat di desa Begitu juga dengan pelaksanaan adat dan budaya seperti upacara adat bersih dusun (rasulan) yang menjadi kewenangan asli desa. Namun, sejauh ini kewenangan berdasarkan hak asal usul masih sebatas itu, tanpa menyentuh aspek substansial, yaitu kewenangan di bidang pemerintahan. Fakta ini juga menegaskan bahwa otonomi desa yang bersumber pada hak asal usulnya belum terlaksana sesuai dengan hakikatnya. Padahal otonomi desa ini sangat penting untuk membangun kapasitas, baik institusi pemerintahan maupun masyarakat. IRE (2005) menjelaskan bahwa tujuan pelaksanaan otonomi desa ini adalah mendekatkan perencanaan pembangunan ke masyarakat, memperbaiki pelayanan publik dan menciptakan efisiensi pembiayaan pembangunan yang sesuai dengan kebutuhan lokal. Namun, yang lebih penting dari itu adalah meningkatkan kesejahteraan masyarakat di desa dan menggerakkan ekonomi lokal dan penghidupan masyarakat desa.

Sama dengan nagari di Sumatera Barat, desa di Yogyakarta juga memiliki sumber daya ekonomi yang dapat dimanfaatkan baik secara perorangan maupun kelompok. Di Sumatera Barat dikenal dengan tanah ulayat. Hanpir setiap nagari memiliki tanah ulayat ini yang kepemilikannya di atur secara adat. Sementara desa di Yogyakarta memiliki tanah bengkok yang dapat dimanfaatkan untuk peningkatan perekonomian desa dan ini bergantung pada pemanfaatan yang diinginkan oleh kepala desa. Walaupun begitu, tanah bengkok yang dimiliki desa ini sebenarnya berasal dari Sultan ground yang pemanfaatannya harus mendapat izin dari Sri 
Sultan yang secara adat budaya adalah raja bagi masyarakat di Yogyakarta. ${ }^{4}$ Dilihat dari nilai strategisnya, baik tanah ulayat maupun tanah bengkok ini sebenarnya menjadi dasar yang dapat menunjang pelaksanaan otonomi di tingkat pemerintahan terendah tersebut.

Tabel 1 Potensi pengembangan Otonomi Asli di nagari dan desa

\begin{tabular}{|c|c|c|}
\hline \multirow{2}{*}{ Potensi sumber otonomi } & \multicolumn{2}{|c|}{ Pemerintah Terendah } \\
\hline & Nagari & Desa \\
\hline Tanah Ulayat & $\begin{array}{l}\text { Dimiliki dan dimanfaatkan } \\
\text { oleh masyarakat berdasarkan } \\
\text { keputusan penghulu adat } \\
\text { untuk kepentungan } \\
\text { kaum/suku di nagari }\end{array}$ & \\
\hline Tanah Bengkok & & $\begin{array}{l}\text { Dimiliki oleh Sultan dan } \\
\text { pemanfaatannya dapat } \\
\text { dikuasai oleh kepala desa } \\
\text { baik untuk kepentingan } \\
\text { pribadi maupun kepentingan } \\
\text { masyarakat desa }\end{array}$ \\
\hline \multirow[t]{2}{*}{ Nilai adat dan budaya } & $\begin{array}{l}\text { Tidak hanya sebagai dasar } \\
\text { ikatan kebersamaan dalam } \\
\text { masyarakat, tapi juga dasar } \\
\text { pembagian kewenangan dari } \\
\text { urusan pemerintahan yang } \\
\text { ada di nagari dan jorong }\end{array}$ & $\begin{array}{l}\text { Sebagai dasar ikatan } \\
\text { kebersamaan dalam } \\
\text { masyarakat, namun tidak } \\
\text { berimplikasi pada } \\
\text { penyelenggaraan urusan } \\
\text { pemerintahan di desa } \\
\text { maupun dusun }\end{array}$ \\
\hline & $\begin{array}{l}\text { Sumber kekuasaan yang } \\
\text { dapat digali dari nilai adat } \\
\text { dan budaya cenderung } \\
\text { terpencar di setiap nagari }\end{array}$ & $\begin{array}{l}\text { Sumber kekuasaan yang } \\
\text { digali dari nilai adat dan } \\
\text { budaya di desa cenderung } \\
\text { terintegrasi pada kekuasaan } \\
\text { raja }\end{array}$ \\
\hline
\end{tabular}

Sejauh ini, adanya pelimpahan kewenangan yang dilakukan pemerintah kabupaten ke pemerintah nagari atau desa ini jelas mengurangi beban kerja yang ada di kabupaten. Di Sumatera Barat, misalnya, berdasarkan Pasal 10 Peraturan Daerah Kabupaten Agam No.12/2007 tentang Pemerintahan Nagari di Kabupaten Agam setiap nagari menerima limpahan urusan dari pemerintah kabupaten dengan kriteria urusan yang dapat meningkatkan pelayanan dan pemberdayaan masyarakat. Memang dalam Pasal 6 huruf b Peraturan Daerah Kabupaten Agam No.9 tahun 2011 tentang penyelenggaraan urusan pemerintahan di Kabupaten Agam dinyatakan bahwa untuk menyelenggarakan urusan pemerintahan tersebut pemerintah kabupaten dapat saja "...menugaskan dan atau menyerahkan sebagian urusan pemerintah tersebut kepada pemerintah nagari berdasarkan asas tugas pembantuan." Namun, ketika urusan tersebut dilimpahkan kepada pemerintah nagari, tidak semuanya dapat dilaksanakan dengan baik.

Dalam banyak hal, pelimpahan urusan pemerintahan kepada pemerintah nagari di Kabupaten Agam ini telah menghilangkan hakikat otonomi yang dititikberatkan di nagari berdasarkan hak asal usulnya. Nagari-nagari di Kabupaten Agam tidak lagi perhatian pada usahanya menggali apa yang menjadi otoritasnya yang otonom tersebut. Padahal dengan menggali potensi otonomi nagari ini sebenarnya dapat memperkuat fungsi nagari yang terdapat dalam Perda No.12/2007 tersebut. Namun, menurut wali Nagari Simarasok, Perda ini tidak memuat kewenangan apa yang semestinya dapat diselenggarakan nagari sesuai dengan hak asal usulnya. Akibatnya, hingga saat ini pemerintah nagari hanya bisa melaksanakan urusan yang ditetapkan untuk dilimpahkan oleh pemerintah kabupaten. ${ }^{5}$

Desa-desa di DI Yogyakarta juga tidak dapat mengenal lebih jauh apa yang menjadi hak asal-usulnya. Otonomi asli yang dinyatakan dalam peraturan perundangundangan ternyata sulit ditemukan. Misalnya, Perda Gunung Kidul No.17/2006 tentang pedoman penyusunan organisasi dan tata kerja pemerintahan desa yang tidak mengatur tentang kewenangan yang bersumber dari hak asal usul. Pada umumnya kewenangan dan urusan pemerintahan desa, misalnya di Desa Ponjong diturunkan dari perangkat daerah yang ada di kecamatan. Dalam hal ini urusan yang diselenggarakan oleh pemerintah desa lebih bersifat administratif. Hal ini tentu berbeda dengan hakikat otonomi asli yang justru menyentuh aspek ekstraksi, distribusi dan regulasi sesuai dengan dinamika masyarakat di desa tersebut. Sayangnya, ini belum dapat dilaksanakan karena aturan yang menjamin pelaksanaan otonomi asli ini belum ada. ${ }^{6}$

Tentu melimpahkan urusan pemerintah kabupaten yang notabenenya adalah daerah otonom mengandung dilemanya. Kalau sebagian besar urusan tersebut dilimpahkan ke pemerintah nagari atau desa, lalu urusan apa yang masih tertinggal menjadi urusan pemerintah kabupaten? Justru dengan pelimpahan urusan berdasarkan asas tugas pembantuan ini membuat pemerintah

5 Wawancara dengan Muslim Dt. Payung Diaceh pada 4 Juli 2013

6 Wawancara Siswanto Kabag Administrasi Pemerintahan Desa Kab. Gunung Kidul pada 25 Juni 2013 Sekretariat Pemda Kab Gunung Kidul DIY 
nagari hanya fokus mengurus apa yang semestinya menjadi urusan pemerintah kabupaten saja. Sementara, upayanya untuk mengeksplorasi kewenangan berdasarkan hak asal usulnya tidak dapat dilaksanakan. Fenomena ini jelas tidak sesuai dengan apa yang dimaksudkan oleh UU pemerintahan daerah yang mengakui adanya hak asal usul masyarakat di tingkat terendah.

Hak asal usul ini jika diperluas sesung-guhnya terkait dengan sejarah terbentuknya nagari atau desa tersebut. Menariknya, ke-tika nagari di Sumatera Barat terbentuk, kehadirannya justru mendahului sejarah negara bangsa Indonesia ini. Artinya, se-belum republik ini merdeka, tentu nagari juga memiliki pemerintahan yang berdaulat, terutama mengatur kehidupan masyarakatnya.Walaupun pemerintahan tersebut diselenggarakan dalam arti tradisional, namun yang jelas pemerintah nagari pada masa ini memiliki kewenangan dan urusan yang diselenggarakannya (cf. Oki, 1977; De Jong 1952). Inilah sesungguhnya hakikat hak asal usul ini. Akan tetapi, setelah negara mengintegrasikan pelaksanana urusan pemerintahan dalam kerangka negara modern, maka hak asal usul dalam konteks otonomi nagari ini menjadi lebur ke dalam urusan pemerintahan modern di tingkat terendah. Hal ini jelas menyisakan pertanyaan, hak asal usul seperti apa yang masih diakui pemerintah sesuai dengan undang-undang pemerintah daerah kalau semuanya sudah dilebur ke dalam penyelenggaraan urusan pemerintahan modern?

Memang Perda Agam No.12/2007 masih ditegaskan adanya kewenangan nagari berdasarkan hak asal-usul ini. Namun, karena pemerintah nagari dibebani dengan pelaksanaan urusan pemerintahan oleh pemerintah kabupaten kecuali urusan adat dan budaya, maka urusan berdasarkan hak asal usul ini tidak jelas bentuknya. Ini memang menjadi paradoks di tengah pengakuan negara terkait dengan hak asal-usul nagari tersebut. Padahal mengidentifikasi hak asalusul ini kembali jauh lebih penting, paling tidak dapat mem-bantu pemerintah kabupaten dan nagari mendefenisikan kembali hakikat otonomi daerah yang dilaksanakan.

Sebenarnya pelaksanaan otonomi daerah di kabupaten/kota berdasarkan UU No.32/2004 memang masih sebatas memenuhi kondisi yang dinyatakan oleh undang-undang. Walaupun, otonomi daerah mengandung pengertian adanya unit-unit di pemerintahan yang dapat membuat, melaksanakan, membiayai dan mengevaluasi kebijakan yang dibuat terkait dengan pelaksanaan fungsi pemerintahan, namun praktiknya tidak sepenuhnya dapat dilaksanakan, khususnya di nagari. Kenyataannya, pelaksanaan otonomi daerah di Kabupaten Agam adalah bagian dari peran pemerintah nagari menyelenggarakan urusan pemerintahan yang dilimpahkan kepadanya. Memang tidak semuanya dapat dilaksanakan dengan baik, namun karena pelimpahan ini, maka beban pemerintah kabupaten sudah dapat dibagi kepada pemerintah di nagari. Apalagi untuk mendukung pelaksanaan urusan ini, maka pemerintah nagari juga memperkuatnya dengan menerbitkan peraturan nagari. Fenomena ini jelas pengejawantahan “otonomi nagari” itu sendiri. Namun faktanya, peraturan nagari yang dibuat tersebut bukan dalam konteks otonomi kewenangan berdasarkan hak asal usul yang dinyatakan dalam peraturan perundang-undangan.

Berman (2003:4) menegaskan otonomi berhubungan dengan seberapa banyak kekuasaan yang dimiliki oleh unit pemerintah tersebut. Dalam hal ini, baik nagari di Sumatera Barat maupun desa di daerah lain juga menghasilkan peraturan yang menjadi dasar pelaksanaan urusan pemerintahan yang diserahkan pemerintah kabupaten. Bahkan proses pembuatan peraturan nagari atau peraturan desa tersebut melalui proses politik yang menggambarkan dinamika politik antara lembaga eksekutif dan legislatif di nagari. Jika pemerintah kabupaten/kota menerima urusan yang diserahkan oleh pemerintah berdasarkan PP No.38/2007 dan melaksanakannya sebagai bentuk urusan pemerintahan yang otonom. Hal yang sama juga mestinya berlaku pada pemerintah nagari atau desa yang juga menerima urusan dari pemerintah kabupaten berdasarkan Perda yang dibuat. Yang membedakan pe- 
nerimaan urusan pemerintahan oleh kedua level pemerintah tersebut hanya pada asasnya saja. Jika penyerahan urusan oleh pemerintah ke kabupaten didasarkan pada asas desentralisasi, maka pada pemerintah nagari atau desa didasarkan pada asas tugas pembantuan.

Padahal dalam sejarahnya, nagari di Sumatera Barat adalah unit politik dan pemerintahan yang otonom tidak hanya dalam penyelenggaraan urusan sosial budaya dan adat istiadat, tapi juga melaksanakan hak asal-usulnya termasuk ke dalamnya urusan pemerintahan. Menariknya, justru pelaksanaan fungsi pemerintahan ini berbeda-beda di setiap nagari karena legitimasinya berdasarkan nilai adat dan tradisi yang juga berbeda pada setiap nagari. Istilah adat salingka nagari (adat selingkar nagari) menggambarkan dasar legitimasi pelaksanaan urusan pemerintahan berdasarkan adat yang berbeda di setiap nagari (Navis, 1984). Artinya, setiap nagarinagari yang ada itu adalah otonom dengan urusan pemerintahannya sendiri. Bahkan nagari-nagari yang bernaung di bawah Kerajaan Pagaruyung adalah dalam bentuk konfederasi. Ini adalah implikasi hakikat dari nagari yang merupakan kesatuan masyarakat hukum adat yang berhak dan mengurus rumah tangganya sendiri tersebut. Ini juga dibuktikan dengan adanya pembedaan pelaksanaan urusan pemerintahan di Sumatera Barat ini melahirkan dua bentuk sistem pemerintahan tradisional (adat), yakni berdasarkan kelarasan bodi chaniago dan kelarasan koto piliang (Oki, 1977). Bahkan dalam perkembangannya pada masa itu, lahir juga kelarasan ketiga yang berada di antara adat dan tradisi pada kedua kelarasan sebelumnya, yakni kelarasan nan panjang (Musyair Zainuddin, 2010). Ketiga kelarasan ini masih ditemukan dalam struktur adat di nagari-nagari di Sumatera Barat pada masa sekarang. Akan tetapi, yang sulit ditemukan adalah pelaksanaan urusan pemerintahan berdasarkan hak asal usul ini yang tidak dapat dijumpai dalam penyelenggaraan pemerintahan sehari-hari.

Begitu juga dengan desa yang mengalami pasang surut sejarah yang berdampak pada bentuknya hingga saat ini. Misalnya, perubahan yang dilakukan pada masa Presiden Soekarno yang dapat dilihat dari struktur organisasi desa yang otonom, lembaga perwakilan masyarakat yang berperan dalam menyuarakan kepentingan masyarakat desa, dan perluasan peran partai politik hingga ke desa sebagai basis politiknya (Budi Winarno, 2003:195-196). Namun, pada masa pemerintahan Presiden Soeharto terjadi perubahan yang signifikan pada struktur organisasi desa yang tidak lagi didorong menjadi lembaga yang otonom. Selain itu, masyarakat desa juga dijauhkan dari aktivitas politik yang berdampak pula pada pembatasan peran partai di tingkat desa. Turunnya rezim Orde Baru mendorong terjadi proses demokrasi hingga ke tingkat lokal. Bahkan pemerintah memilih jargon demokrasi lokal sebagai basis pembangunan demokrasi di tingkat nasional. Kebijakan desentralisasi di kabupaten/kota diselaraskan dengan otonomi asli desa. Sayangnya, otonomi asli berdasarkan hal asal usul ini, yaitu menyelenggarakan pemerintahan sendiri (self bestuur) ternyata belum dapat dilaksanakan sesuai dengan jaminan oleh konstitusi.

\section{Dampak Pelimpahan Urusan Pemerintahan Pada Otonomi Nagari Dan Desa}

Dengan adanya pelimpahan urusan pemerintahan ke nagari oleh pemerintah kabupaten, maka nagari dan desa hanya melaksanakan urusan yang sebenarnya tidak berasal dari kewenangan asal usulnya. Pada umumnya, pemerintah nagari di Sumatera Barat dan pemerintah desa di Yogyakarta hanya disibukkan dengan urusan yang sudah dilimpahkan oleh pemerintah kabupaten. Dalam, banyak hal, pemerintah nagari dan pemerintah desa sudah dapat melaksanakan urusan pemerintahan sesuai dengan kapasitas yang dimilikinya. Dan, dalam hal tertentu, ada juga urusan yang memang belum dapat diselenggarakan secara maksimal.

Misalnya, di Kabupaten Agam, pemerintah nagari masih menghadapi kendala dalam pelaksanaan pembangunan dan pemberdayaan masyarakat. Memang masalah pembangunan ini selalu bertemu dengan persoalan klasik, yaitu terbatasnya anggaran yang tersedia. Sementara, pelaksanaan fungsi 
pemberdayaan masyarakat terkendala pada sumber daya manusia yang bersedia menjadi relawan dalam melakukan pendampingan kepada masyarakat di nagari. Selain itu, pemerintah nagari, misalnya Nagari Simarasok, mengupayakan adanya bantuan dari perantau yang bersedia membantu penyelenggaraan pemerintahan nagari sehingga tujuan bernagari dapat diwujudkan. Seperti yang ditegaskan oleh Wali Nagari Simarasok,

Sumber daya yang dimiliki nagari pada umumnya relatif rendah, baik sumber daya manusia maupun sumber daya non manusia. Sumber daya aparatur pemerintahan nagari di nagari Simarasok hanya berjumlah 11 orang. 4 orang di antaranya berpendidikan sarjana selebihnya SMA. Walaupun begitu untuk menutupi kekurangan ini, maka pemerintah nagari meminta kesediaan pada perantau yang terdekat untuk menjadi staf ahli, terutama dari kalangan akademisi untuk membantu penyelnggaraan pemerintahan dalam pembuatan perencanaan dan program pembangunan. Selain itu, kami juga meminta mereka untuk melakukan lobi/akses kepada pihak pemerintah/swasta untuk menjaring potensi yang dapat meningkatkan kemajuan nagari ini. ${ }^{7}$

Sementara, dalam pelaksanaan fungsi pelayanan publik sebagian besar sudah dapat dilaksanakan karena menjadi pekerjaan rutin pemerintah nagari. Apalagi sejak kebijakan "kembali ke nagari" dicanangkan, titik berat pelayanan publik dipusatkan di nagari. Karenanya, Pemerintah Kabupaten Agam memberikan bantuan pembiayaan langsung kepada pemerintah nagari, khususnya dalam menyelenggarakan urusan yang dilimpahkannya. Bantuan tersebut dituangkan ke dalam bentuk Anggaran Pendapatan dan Belanja Nagari. Misalnya, pada tahun 2011 Pemerintah Kabupaten Agam telah mengalokasikan dana untuk 82 nagari dalam menyelenggarakan urusan pemerintahan di nagari dalam bentuk Dana Alokasi Umum Nagari (DAUN) yang besarannya berkisar dari Rp. 250 juta hingga Rp. 400 juta untuk setiap nagari. Dari sisi lain, pemerintah ka-

7 Wawancara dengan Muslim Dt. Payung Diaceh, Wali Nagari Simarasok, tanggal 4 Juli 2013. bupaten juga menyediakan Dana Alokasi Khusus yang digunakan membantun nagari melaksanakan fungsi pemerintahan dan juga pemilihan wali nagari dan pemilihan anggota Badan Musyawarah (legislatif) nagari. Untuk dapat memanfaatkan dana ini, maka setiap nagari di Kabupaten Agam menerbitkan Peraturan Nagari terkait dengan DAUN dan biaya pelayanan yang dibebankan kepada masyarakat dalam menerima pelayanan tersebut. Dari aspek ini jelas, bahwa kewenangan menerbitkan peraturan nagari ini adalah bagian dari ciri pemerintahan yang otonom yang proses dibahas melalui badan musyawarah nagari (badan legislatif di nagari).

Hal yang sama juga terjadi di Desa Ponjong Kabupaten Gunung Ki-dul. Pemerintah desa masih memiliki keterbatasan dalam melaksanakan fungsi pemerintahan. Adanya keterbatasan ini menjadi pertimbangan bagi pemerintah kabupaten untuk menyerahkan urusan pemerintahan apa yang dapat diserahkan kepada pemerintah desa. Akibatnya tidak semua desa memiliki urusan yang sama. Peimpahan urusan ke pemerintahan desa sangat bergantung pada kesiapan pe-merintah desa dari aspek potensi daerah dan manusianya. Seperti yang dijelaskan oleh Siswanto:

Urusan pemerintahan desa ini tidak diserahkan secara merata di antara desadesa yang ada, melainkan berdasarkan kemampuan yang dimiliki oleh desa dengan pertimbangan inovasi dan kreatifitas pemerintah desa dalam melaksanakan urusan pemerintahan di tingkat terendah. Terkait dengan itu, pemerintah juga menyerahkan Alokasi Dana Desa yang rentangnya per desa, yaitu terendah 53 juta dan tertinggi 78 juta. $^{8}$

Sebenarnya, jika dipahami lebih jauh bahwa keberhasilan pemerintah nagari dan pemerintah desa melaksanakan urusan yang dilimpahkan kepadanya tidak terlepas dari peran pemerintah kabupaten memfasilitasi apa yang menjadi kebutuhan dasar dari nagari dan desa di kedua daerah tersebut. Bahkan dalam upaya pelaksanaan fungsi pembangunan dan pemberdayaan

8 Wawancara dengan Kabag Administrasi Pemerintahan Desa Kab. Gunung Kidul pada 25 Juni 2013 Sekretariat Pemda Kab Gunung Kidul DI Yogyakarta. 
masyarakat di nagari, juga terdapat peran pemerintah pusat. Contohnya, pelaksanaan program pembangunan di Kabupaten Agam di Sumatera Barat yang juga dibantu oleh pemerintah pusat dalam pelaksanaan Program Nasional Pemberdayaan Masyarakat Mandiri Perdesaan (PNPM-MP) yang mencapai Rp. 28,9 milyar pada tahun 2013. Jumlah ini meningkat sebesar 140 persen dibandingkan dengan tahun 2012 yang hanya memperoleh Rp. 12.651 milyar.

Tentu peningkatan ini menjadi stimulasi bagi pemerintah nagari untuk berprestasi melaksanakan urusan yang dilimpahkan kepadanya. Tujuannya jelas agar otonomi daerah yang dilaksanakan dapat menyentuh tingkat terbawah pemerintahan yang juga memiliki penduduk.

Sementara itu, Pemerintah Kabupaten Gunung Kidul juga mendapat bantuan dari pelaksanaan PNPM-MP tahun 2013 ini sebesar Rp. 46,076 milyar. Selain itu, pemerintah kabupaten juga menyediakan dana pendampiang sebesar Rp. 3,425 milyar untuk membantu pelaksanaan pemberdayaan masyarakat ini. Untuk Kecamatan Ponjong, jumlah bantuan yang diterima sebesar Rp. 2,850 milyar dari PNPM-MP dan Rp. 150 juta dari pemerintah kabupaten. Dana ini dapat menjadi stimulus bagi masyarakat untuk menggerakan potensi desa yang mereka miliki. Selain membawa arti yang positif bagi masyarakat, pembiayaan melalui Program PNPM-MP sebenarnya membawa dampak negatif, terutama keinginan masyarakat untuk mengembangkan hal asal-usul yang mereka miliki. Karena pemerintah nagari dan desa sudah terbiasa menerima insentif pelaksanaan fungsi pemerintahan yang dilimpahkan kepadanya sehingga melupakan otonomi asli yang menjadi hak mereka.

Misalnya di Sumatera Barat, terkait dengan pengelolaan tanah ulayat yang menjadi bagian dari kewenangan yang berdasarkan hak asal usul nagari. Tanah ulayat adalah bidang tanah yang di atasnya terdapat hak ulayat dari suatu masyarakat hukum adat tertentu. Jadi sesuai dengan hak asal usul nagari yang keberadaannya ditandai dengan keberadaan tanah ulayat ini semestinya menjadi bagian urusan pemerintah nagari. Namun, faktanya tidak demikian karena pemanfaatan tanah ulayat ini juga diatur oleh pemerintah. Sepanjang pemanfaatannya sejalan dengan semangat UU, maka tanah ulayat dapat dikelola oleh masyarakat di nagari. Inilah bukti bahwa pengakuan terhadap hak asal usul ini hanya simbolis semata. Fakta lain, kucuran dan yang besar dari pemerintah juga berdampak pada orientasi elite tradisional di nagari yang rela memecah satu menjadi dua nagari karena motif uang. Dengan berbagai justifikasi baik ekonomi, politik dan sosial dan budaya, maka nagari dimekarkan. Namun, fenomena ini juga memutus ikatan emosional, kebersamaan, kekeluargaan dan modal sosial yang hidup dalam masyarakat nagari. Namun, orientasi kapitalisme yang sejalan dengan praktik demokrasi liberal yang diadopsi pemerintah berakibat pada nagari.

Keadaan ini jelas berdampak negatif bagi pendalaman demokrasi di tingkat lokal karena pemerintah cenderung mengabaikan kewenangan nagari yang otonom. Idealnya, nagari juga menyelenggarakan urusan yang melekat dengan pengakuan negara terhadap hak asal usulnya. Apalagi di Sumatera Barat, pelaksanaan kewenangan pemerintah nagari mengalami perubahan sejak diberlakukannya kebijakan kembali ke nagari tahun 2000. Pemerintah memisahkan kewenangan para penghulu di nagari yang hanya mengurusi masalah adat dan budaya; mereduksi kewenangan mereka yang sebenarnya memiliki otoritas di bidang pemerintahan. Kenyataannya, sejak dilaksanakannya otonomi daerah yang diikuti dengan kebijakan pemerintah pro-vinsi mengintegrasikan penyelenggaraan pemerintahan nagari ke dalam pemerintahan modern, penghulu mulai kehilangan otoritasnya dalam penyelenggaraan pemerintahan (Asrinaldi \& Yoserizal, 2011b).

Jadi, adanya kebijakan pemerintah menitikberatkan urusan otonomi di tingkat kabupaten/kota ini juga berdampak pada pengabaian terhadap aktivitas masyarakat hukum adat pada nagari yang ada di 
Sumatera Barat. Keadaan ini juga ditemukan dalam penyelenggaraan kehidupan bernagari di Kabupaten Agam. Pemerintah daerah cenderung membiarkan masyarakat hukum adat untuk menemukenali apa yang menjadi urusan otonominya. Pemerintah Kabupaten Agam justru lebih mendorong pemerintah nagari melaksanakan kewenangan penugasan dari mereka ketimbang menggali hakikat otonomi berdasarkan hak asal-usul tersebut.

Di Provinsi DI Yogyakarta, pemanfaatan tanah kas desa (bengkok) sangat bergantung pada izin yang diberikan Sri Sultan sebagai pemilik sultan ground. Izin dari Sri Sultan sangat bergantung pada rekomendasi yang diberikan oleh pemerintah kabupaten yang disesuaikan dengan Rencara Tata Ruang dan Tata Wilayah dari kabupaten tersebut. Apabila pemanfaatan tanah kas desa tersebut sesuai dengan RTRW kabupaten, maka biasanya Sri Sultan sebagai pemilik wilayah menyerahkannya kepada masyarakat desa. Dengan dimanfaatkannya sultan ground ini, maka desa dapat menjadi mandiri karena dapat membiayai pelaksanaan fungsi pemerintahan yang dilimpahkan kepada pemerintah desa.

Di sinilah letak perbedaan sumber otonomi asli yang berdasarkan hak asal usul yang harus digali oleh masyarakat di nagari maupun di desa. Dalam sejarahnya, nagari-nagari di Sumatera Barat bergabung ke dalam konfederasi bawah panji Kerajaan Pagaruyung sehingga memiliki wilayah yang otonom. Faktanya kekuasaan Kerajaan Pagaruyung cenderung hanya bersifat keluar dan bukan ke dalam aktivitas bernagari. Ini berbeda dengan desa di Yogyakarta yang sumber kekuasaannya berdasarkan sejarah raja-raja cenderung terpusat di tangan Sri Sultan. Aspek kesejarahan ini berpengaruh pada penyelenggaraan otonomi asli desa yang sangat bergantung pada sejarah Kerajaan Mataram.

\section{SIMPULAN}

Prinsip desentralisasi yang dilaksanakan dalam penyelenggaraan pemerintahan di daerah diturunkan dalam bentuk pengakuan adanya daerah otonom di kabupaten/ kota. Oleh pemerintah, maka pelaksanaan otonomi daerah ini diselenggarakan dengan menyerahkan sebagian besar kewenangan dan urusan pemerintahan kepada daerah. Namun, dalam praktik sehari-hari, urusan pemerintahan yang diterima kabupaten/ kota justru dilimpahkan kembali kepada pemerintah terendah baik nagari ataupun desa. Hal ini tentu berimplikasi pada pemaknaan titik berat otonomi daerah di kabupaten/kota berdasarkan UUNo.32/2004. Pemerintah kabupaten tidak lagi sepenuhnya menyelenggarakan urusan yang diserahkan kepadanya, terutama yang terkait dengan pelayanan publik yang sering dibutuhkan masyarakat. Sebagian urusan pelayanan publik tersebut dikerjakan oleh pemerintah nagari dan desa sebagai bagian subordinasi dari pemerintah kabupaten. Namun, dari segi lain, nagari atau desa ternyata juga memiliki otonomi yang berasal dari hak asal usulnya. Bahkan negara mengakui adanya hak asal usul yang dimiliki nagari dan desa ini.

Realitanya, kewenangan pemerintah nagari/desa yang memiliki hak otonomi ini tidak pernah dapat diindentifikasi maksimal oleh pemerintah nagari di Sumatera Barat atau pemerintah desa di Yogyakarta. Dalam konteksnagari,haliniterjadikarenakesibukan pemerintah nagari yang menyelenggarakan urusan pemerintahan yang dilimpahkan oleh pemerintah kabupaten. Kecuali urusan adat dan budaya seperti yang kental dilaksanakan pada nagari-nagari di Kabupaten Agam, urusan pemerintahan yang menjadi bagian dari proses terbentuknya nagari karena adanya hak asal usul ini seperti pengelolaan tanah ulayat, kehutanan tidak dapat dilaksanakan dengan baik. Dengan kata lain, otonomi nagari yang berdasarkan hak asal-usul seperti yang dijamin oleh undangundang hanyalah semu belaka, tanpa mampu dilihatkan bentuk aslinya, apalagi untuk dilaksanakan oleh kesatuan masyarakat hukum adat. Begitu juga desa-desa di Yogyakarta hanya menerima pelimpahan urusan yang dilimpahkan oleh pemerintah kabupaten. Inilah realitanya bahwa pemerintah memang mengabaikan hak asal usul sehingga yang dilaksanakan sebenarnya adalah quasi otonomi di nagari dan desa 
yanghanyabertujuanuntukmemperkuatotonomidi kabupaten yang diinginkan pemerintah. Idealnya, pemerintah mendorong penyelenggaraan pemerintahan di tingkat terendah seperti nagari dan desa untuk menemukan bentuk otonomi asli berdasarkan hak asal-usul tersebut.

\section{DAFTAR PUSTAKA}

Antlov, H. 2003. Village government and rural development in Indonesia: the new democratic framework. Bulletin of Indonesian Economic Studies 39(2): 193-214.

Aspinall, E \& Fealy, E. (Eds.). 2003. Introduction: decentralisation, democratisation and the rise of the local. Dlm. E. Aspinall \& G. Fealy (Eds.). Local power and politics in Indonesia: decentralization \& democratization, hlm. 1-14. Singapore: Institute of Southeast Asian Studies.

Asrinaldi, 2012. Implementasi demokrasi lokal di balik bayang-bayang otonomi negara. Jurnal masyarakat, kebudayaan dan politik 25(2):96107.

Asrinaldi \& Yoserizal. 2011a. Kembali ke negara: analisis peran otonomi negara dalam mengendalikan proses demokrasi lokal di Sumatera Barat. Laporan Penelitian Fundamental. Universitas Andalas, Padang.

Asrinaldi \& Yoserizal, 2011b. Praktik Pemerintahan Terendah Dalam Pembangunan dan Implikasinya Terhadap Demokrasi Lokal Di Sumatera Barat. Jurnal Transformasi Pemerintahan, 3(2):85-103.

Bakaruddin, Asrinaldi \& Syaiful. 2004. Studi tentang pelaksanaan pelayanan publik pada pemerintahan nagari di Kabupaten Solok. Laporan Penelitian. Padang: Pusat Studi Otonomi Daerah.

Bank Dunia. 2004. Inovasi pelayanan pro miskin: Sembilan studi kasus di Indonesia. Jakarta: Perwakilan Bank
Dunia \& Indopov.

Berman, D. R. 2003. Local government and states: autonomy, politics, and policy. New York: M.E. Sharpe, Inc.

Cheema, G. S. 2005. Building democratic institutions: governance reform in developing countries. New York: Kumarian Press.

De Jong, P.E. 1952. Minangkabau and Negeri Sembilan: socio-political structure in Indonesia. Hague: Martinus Nijhoff.

Falleti, T. G. 2010. Decentralization and subnational politics in Latin America. Cambridge: Cambridge University Press.

I Nyoman Sumaryadi. 2005. Efektifitas implementasi kebijakan otonomi daerah. Jakarta: Depok Citra Utama.

IRE. 2005. Otonomi desa. Yogyakarta: APMD Press.

Kaloh, J. 2003. Mencari bentuk otonomi daerah. Jakarta: Rineka Cipta.

Musyair Zainuddin. 2010. Implementasi pemerintahan nagari berdasarkan hak asal-usul adat Minangkabau. Yogyakarta: Ombak.

Navis, A.A. 1984. Alam terkembangjadi guru: adat dan kebudayaan Minangkabau. Jakarta: Grafiti Pers.

Nordholt, H.S \& Klinken, G.V. 2007. Pendahuluan. Dlm. H. S. Nordholt \& G. V Klinken (Eds.). Politik lokal di Indonesia, hlm. 1-41. Terj. Bernard Hidayat. Jakarta: YOI \& KITLV.

Nordlinger, E. A. 1981. On the autonomy of the democratic state. Cambridge: Harvard University Press.

Oki, A. 1977. Social change in the West Sumatran village 1908-1945. Thesis Doctor of Philosophy. Australia National University.

R. Yando Zakaria. 2000. Abih tandeh: masyarakat desa di bawah rejim Orde Baru. Jakarta: Elsam.

R. Yando Zakaria, Y. A. 2004. Merebut negara: beberapa catatan reflektif tentang upaya-upaya pengakuan, pengembalian dan pemulihan oto- 
nomi desa. Yogyakarta: Lapera Pustaka Utama.

Rondinelli, D. A., \& Cheema, G. S. 1983. Implementing decentralization policies: an introduction. Dlm. G. S. Cheema \& D. A. Rondinelli (pnyt.), Decentralization and development: policy implementation in developing countries, hlm. 9-34, London: Sage Publication

Ryaas Rasyid. 2005. Otonomi daerah: latar belakang dan masa depannya. Dalam Syamsuddin Haris (Eds.). Desentralisasi, demokratisasi \& akuntabilitas pemerintahan daerah, hal.1-24. Jakarta: LIPI Press.

Seavoy, R. E. 2003. Origins and growth of the global economy: from the fifteenth century onward. Westport, CT: Greenwoods Press.

Skocpol, T. 1985. Bringing the state back in: strategies of analysis in current research. Dlm. Peter B. Evans, Dietrich Rueschemeyer \& Theda Skocpol (pnyt.). Bringing the state back in, hlm. 3-44. Cambridge: Cambridge University Press.

Smith, B.C. 1985. Decentralization: the territorial dimension of the state. London: Allen \& Unwin.

Syarif Hidayat. 2010. Mengurai peristiwa merentas karsa: refleksi satu dasawarsa reformasi desentralisasi dan otonomi daerah. Prisma 29(3):1-22.

Turner, M. \& Hulme, D. 1997. Governance, administration and development: making the state work. Basingstoke: Macmillan.

Winarno, B. 2003. Komparasi organisasi pedesaan dalam pembangunan: Indonesia vis-à-vis Taiwan, Thailand dan Filipina. Yogyakarta: Media Pressindo 